\title{
PREDICTORS OF SUSTAINED RESPONSE TO INTERFERON-BASED THERAPY IN CHRONIC HEPATITIS B
}

\author{
Deian Jelev, Krasimir Antonov, Aneta Ivanova, Zahariy Krastev \\ Clinic of Gastroenterology, \\ St. Ivan Rilsky University Hospital, Sofia, Bulgaria
}

\section{ABSTRACT}

Objective: IFN-based therapy induces long-term remission in $\sim 20 \%$ of CHB-patients. Identification of predictors of treatment response can facilitate the clinical decision.

Methods: 168 CHB-patients treated with IFN-based therapy were studied. Predictors of end-of-treatment response (ETR) and sustained response (SR) one-year post therapy were identified by non-parametric chi-square test and correlation analysis.

Results: Low baseline HBV DNA $(<50,000,000 \mathrm{cp} / \mathrm{ml})$ and high ALT level $(>4 \times \mathrm{xUN})$ were independent predictors of ETR. Low viral load was stronger predictor than high ALT level. If both factors coexist the probability of ETR was $92 \%$. In HBeAg-negative subjects SR correlates significantly with age below 40 years, evidence of early viral response at $3^{\text {rd }}$ month, fibrosis stage $\mathrm{F}<3$ (METAVIR) and prolongation of treatment duration. $\mathrm{HBeAg}$-seroconversion up to 6-month post-therapy was the strongest predictor of SR in HBeAgpositive patients.

Conclusion: More favorable results could be achieved by pretreatment selection according to patients' age, baseline viral load, ALT and liver fibrosis. Extension of IFN-treatment in responders may enhance the SR rate.

Key words: HBV, IFN, Peg IFN, predictors, treatment

\section{INTRODUCTION}

Chronic hepatitis B virus (HBV) infection continues to be a major global health problem with more than 400 million cases worldwide (1). It is a cause of cirrhosis and hepatocellular carcinoma (1). HBeAg-negative chronic hepatitis $\mathrm{B}(\mathrm{CHB})$ is a severe and progressive liver disease with poor prognosis. Spontaneous sustained remissions are very rare and patients early develop cirrhosis (2-4). This type of CHB is predominant in the Mediterranean region, Eastern Europe and Asia and its prevalence is increasing worldwide (5).

Similarly to other South European countries the majority of chronic hepatitis B patients in Bulgaria are $\mathrm{HBeAg-negative.} \mathrm{There} \mathrm{is} \mathrm{a} \mathrm{trend} \mathrm{for} \mathrm{increasing} \mathrm{of} \mathrm{HBeAg}$ - negative $\mathrm{CHB}$ during the last 15 years and nowadays about $80 \%$ of subjects in our country are HBeAg-negative $(6,7)$.

Currently there are two global treatment strategies for patients with CHB: IFN-based therapy and long-term viral suppression with nucleoside/nucleotide analogs. Fixed treatment duration of IFN is a significant advantage, but longterm remission could be achieved only in approximately $20 \%$ of subjects (8). Investigations of predictors of response to IFN-based therapy were focused mainly on patients with HBeAg-positive CHB. Low viral load as well as high ALT level at baseline has been shown to be independently associated with response to IFN and Peg IFN (9 - 11).

In $\mathrm{HBe} A$ g-negative $\mathrm{CHB}$, IFN is associated with good end-of treatment response (ETR), but high rates of early relapse upon treatment discontinuation and poor sustained response (SR) rates (12-15). Identification of predictors of treatment response can facilitate the clinical decision.

\section{MATERIALS AND METHODS \\ Studied patients}

We studied 168 patients with chronic HBV infection who were treated with conventional IFN a2a (112 pts) or Peg IFN a2a (56 pts) - table 1 . All subjects initially were with active viral replication defined as HBV DNA $>10,000 \mathrm{cp} / \mathrm{ml}(>2000$ $\mathrm{IU} / \mathrm{ml}$ ) and with elevated ALT level. Co-infections with HDV, $\mathrm{HCV}$ and HIV were excluded.

Table 1. Baseline patients' characteristics

\begin{tabular}{|lc|}
\hline $\begin{array}{l}\text { Number of patients } \\
\text { Gender } \\
\text { male }\end{array}$ & 168 \\
female & 130 \\
HBeAg & 38 \\
positive & \\
negative & 51 \\
$\begin{array}{l}\text { Age [years] } \\
\text { Median } \\
\text { (min. - max.) }\end{array}$ & 117 \\
& 37 \\
\hline
\end{tabular}




\begin{tabular}{lc|} 
HBV DNA [cp/ml] & \\
Median & 29515000 \\
(min. - max.) & $(24040-752000000$ 000) \\
ALT [x ULN] & \\
$\begin{array}{l}\text { Median } \\
\text { (min. - max.) }\end{array}$ & $\mathbf{3 , 5}$ \\
Liver fibrosis(METAVIR) & $(1,4-7,35)$ \\
F $<2$ & 126 \\
F $>3$ & 33 \\
unknown & 9 \\
\hline
\end{tabular}

All patients were treated with IFN-based therapy according to the relevant knowledge of HBV infection and treatment policy at the corresponding period.

1) Fifty-six of them received Peg IFN alfa-2a

2)112 patients were treated with conventional IFN alfa-2a. Studied patients were treated between 1995 and 2010. Over the years the guidelines for the duration of treatment course evaluated. Due to this reasons 45 patients received 6 month treatment course, while 73 patients were treated for 12 months

3) 40 patients were included in clinical trials and after the initial treatment with "standard" duration they continue to receive further "consolidation" therapy by intermittent application of IFN or Peg IFN in lower doses. The total treatment duration in the discussed group of patients was at least 24 months.

\section{Treatment response}

Virological response both at the end-of-treatment
(ETR) and one year post therapy (sustained response-SR) was defined as HBV DNA level $<10,000 \mathrm{cp} / \mathrm{ml}(<2000 \mathrm{IU} /$ $\mathrm{ml})$. Early virological response was defined as HBV DNA $<$ $10,000 \mathrm{cp} / \mathrm{ml}$ at end of $3^{\text {rd }}$ month of therapy.

\section{Statistics}

Predictors of both ETR and SR were identified by nonparametric chi-square test and correlation.

\section{RESULTS}

ETR was achieved in $98 / 168$ of subjects (58\%). The rest $70 / 168$ of patients $(42 \%)$ were non-responders. Low baseline HBV DNA level $(<50,000,000 \mathrm{cp} / \mathrm{ml})$ and high ALT level ( $>4 \mathrm{x}$ above the upper limit of normal) were identified as independent predictors of ETR.

Initially 101 and 67 subjects were with low and high viral load, defined by rough approximation using histogram. ETR was significantly higher among subjects with HBV DNA $<50,000,000 \mathrm{cp} / \mathrm{ml}$ compared to those with high baseline viral load: 76/101 (75\%) vs. 22/67 (33\%), p( $\left.\mathrm{c}^{2}\right)<$ 0,001 - fig. 1 .

Seventy-three patients were with baseline ALT level $>4$ xULN, while the rest 95 were with lower ALT level. Significantly higher rate of ETR was found among subjects with baseline ALT above 4xULN: 54/73 (74 \%) vs. 44/95 $(46 \%), \mathrm{p}\left(\mathrm{c}^{2}\right)<0,01-$ fig. 1 .

Low viral load was stronger predictor than high ALT level, but if both factors coexist the probability of ETR was $92 \%$ (fig. 1).

Figure 1. ETR according to baseline HBV DNA and ALT levels.

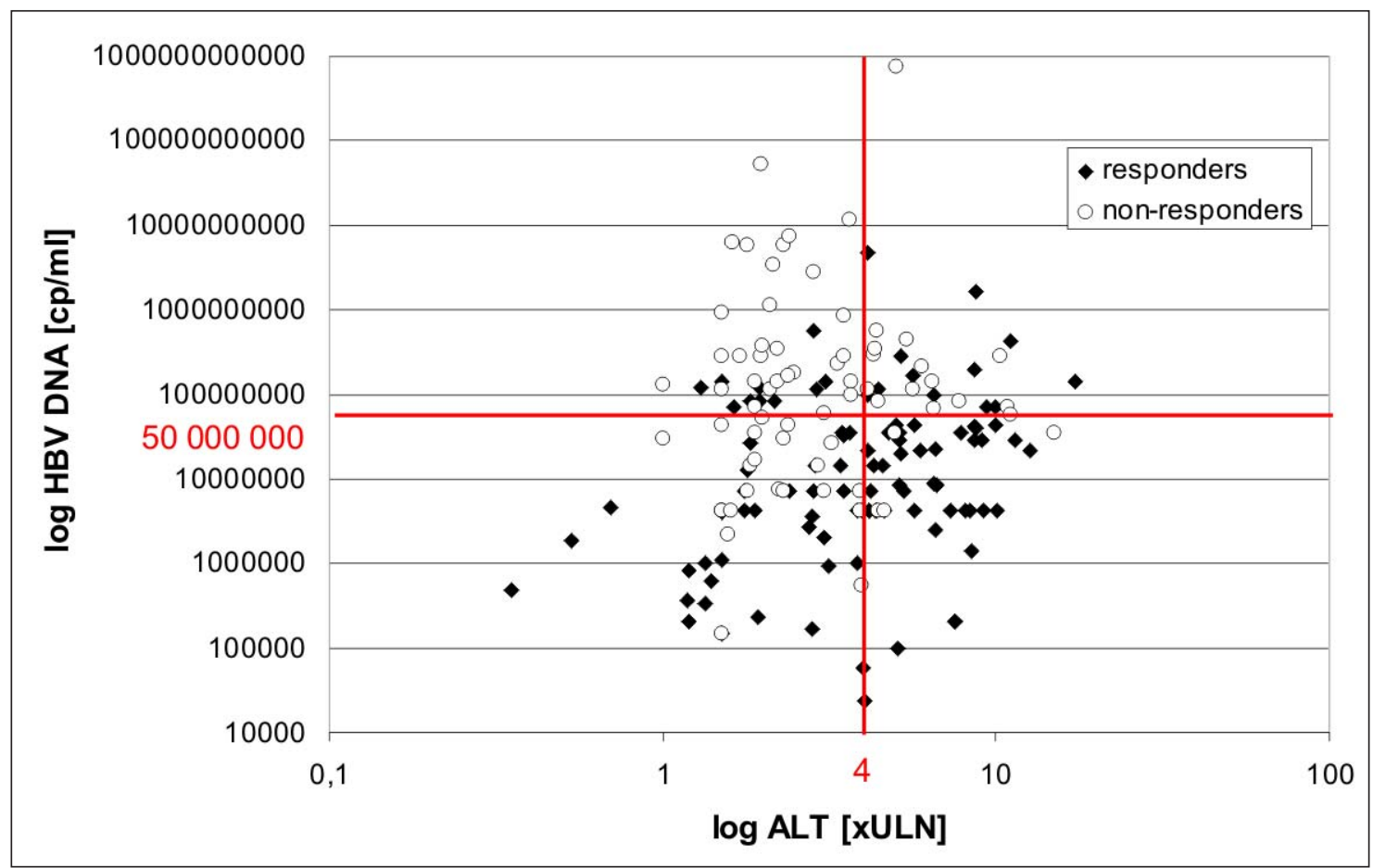


Twelve months post therapy the relapsers were 59/ $98(60 \%)$ of end of treatment responders. Globally 39/168 of patients $(23 \%)$ were with SR.

In $\mathrm{HBeAg}$-negative end-of-treatment responders, SR correlates significantly with age $<40$ years before therapy, evidence of early viral response at $3^{\text {rd }}$ treatment month, lack of advanced fibrosis ( $\mathrm{F}<3$ according to METAVIR) and prolonged treatment duration. Among above factors treatment duration was identified as the strongest predictor of SR (Table 2).

Table. 2. Factors correlated significantly with sustained response

\begin{tabular}{|c|c|c|}
\hline & $\begin{array}{l}\text { Spearman } \\
\text { correlation }\end{array}$ & P value \\
\hline $\begin{array}{l}\text { Treatment duration } \\
\text { (>24 months) }\end{array}$ & $r=0,65$ & $\mathrm{p}<0.0001$ \\
\hline $\begin{array}{l}\text { Advanced fibrosis } \\
(\mathrm{F}>3)\end{array}$ & $\mathrm{r}=-0,62$ & $\mathrm{p}<0.01$ \\
\hline $\begin{array}{l}\text { Early viral response } \\
\text { (month 3) } \\
\text { Age }\end{array}$ & $\mathrm{r}=0,32$ & $\mathrm{p}<0.05$ \\
\hline$(<40$ years $)$ & $r=0,30$ & $\mathrm{p}<0.05$ \\
\hline
\end{tabular}

Patients' gender, as well as type of IFN (conventional IFN or Peg IFN) was not predictor of SR in both HBeAgnegative and $\mathrm{HBe} A g$-positive subjects.

$\mathrm{HBe} A g$ seroconversion up to 6-month post therapy was the strongest predictor of SR in $\mathrm{HBeAg}$-positive patients.

\section{DISCUSSION}

The current study describes the first detailed analysis of predictors of response to IFN-based therapy in Bulgarian patients with chronic HBV infection. Our results confirmed previous findings that baseline viral load and ALT level are strong predictors of response to both conventional and pegylated IFN therapy $(9-11,15)$. In our study the threshold of baseline HBV DNA $<50,000,000 \mathrm{cp} / \mathrm{ml}$ was quite similar to the results of R. Perrillo et al. for favorable treatment response to conventional IFN in patients with HBV DNA $<200 \mathrm{pg} / \mathrm{ml}(\sim 56,600,000 \mathrm{cp} / \mathrm{ml})(9)$. Furthermore, in the study of F. Bonino et al. the reported baseline ALT level $>5 \mathrm{x}$ ULN was also similar to our findings that ALT $>$ $4 \mathrm{x}$ ULN is good predictor of treatment response (15). Our results confirmed data of previous trails for better treatment response in young subjects without cirrhosis or advanced liver fibrosis $(9,10)$.

Recently HBV genotype was also identified as a significant predictor of response to pegylated IFN therapy $(11,15)$. We have not analyzed this factor because genotype $\mathrm{D}$ is predominant in Bulgaria and near 100\% of CHB patients in our country are infected with genotype $\mathrm{D}$. This genotype was found in all patients enrolled in the National, Multicenter study with Peg interferon alfa-2a (16). In addition, predomination of genotype $\mathrm{D}$ has been confirmed recently also in patients with acute hepatitis B (17). And finally, genotype D was detected in all 25 pts tested for HBV genotype in the present study. Based on all these data one can speculate that present study demonstrate the predictors of IFN-based therapy in subjects with HBV genotype D.

Predictors of treatment response were analyzed mainly in patients treated for up to 1 year. A significant advantage of our study is a group of 40 patients who received prolonged IFN-based therapy for at least 24months. We identified the prolongation of treatment duration as the strongest predictor of sustained response among HBeAg-negative patients. Our results corresponded to recent findings in $\mathrm{HBeAg}$-negative $\mathrm{CHB}$ patients with genotype D (18). P. Lampertico et al. clearly demonstrated that extension of treatment course from 48 to 96 weeks is associated with increased sustained response rate from $10 \%$ to $31 \%$ at 1 -year post therapy. In addition HBsAg clearance increased from $0 \%$ to $6 \%$, respectively (18). Together all these results clearly suggested that extension of treatment duration in $\mathrm{HBeAg}$ - patients may consolidate the early virological response and thus to reduce the relapse rate after treatment discontinuation.

\section{CONCLUSION}

Higher rate of SVR with IFN based therapy could be achieved by precise pretreatment selection according to patients' age, baseline viral load, ALT levels and absence of advanced liver fibrosis. Extension of treatment course in subjects with early virological response may enhance the long-term sustained response rate. 


\section{REFERENCES:}

1. Lavanchy D. Hepatitis B virus epidemiology, disease burden, treatment, and current and emerging prevention and control measures. J Viral Hepat. 2004 Mar;11(2): 97-107. DOI: 10.1046/j.13652893.2003.00487.x CrossRef] [PubMed]

2. Bonino F, Rosina F, Rizzetto M, Rizzi R, Chiaberge E, Tardanico R, et al. Chronic hepatitis in HBsAg carriers with serum HBV-DNA and anti-HBe. Gastroenterology 1986 May;90(5Pt 1): 1268-73. [PubMed]

3. Hadziyannis SJ. Hepatitis B e antigen negative chronic hepatitis B: from clinical recognition to pathogenesis and treatment. Viral Hep Rev 1995; 1:7-36.

4. Brunetto MR, Oliveri F, Coco B, Leandro G, Colombatto P, Gorin JM, Bonino F. Outcome of anti-HBe positive chronic hepatitis B in alpha-interferon treated and untreated patients: a long term cohort study. J Hepatol. 2002 Feb; 36(2): 263-70. [PubMed]

5. Funk ML, Rosenberg DM, Lok ASF. World-wide epidemiology of $\mathrm{HBeAg}$ negative chronic hepatitis $\mathrm{B}$ and associated precore and core promoter variants. J Viral Hepat. 2002 Jan;9(1):52-61. DOI: 10.1046/ j.1365-2893.2002.00304.x CrossRef] [PubMed]

6. Antonov A, Krastev Z.. HBeAgnegative chronic hepatitis B. Mod. Medicine 1998, 2, 42-43. (in Bulgarian)

7. Jelev D, Antonov K. Differences between $\mathrm{HBeAg}$-positive and $\mathrm{HBeAg}$ negative chronic hepatitis $\mathrm{B}$. Bulgarian Hepatogastroenterology 2002, 3, 69-71. (in Bulgarian)

8. EASL. Clinical Practice Guidelines: management of chronic hepatitis B. J
Hepatol., 2009 Feb;50(2): 227-42. DOI: 10.1016/j.jhep.2008.10.001 CrossRef] [PubMed]

9. Perrillo RP, Schiff ER, Davis GL, Bodenheimer HC Jr, Lindsay K, Payne J, et al. A randomized, controlled trial of interferon alfa- $2 \mathrm{~b}$ alone and after prednisone withdrawal for the treatment of chronic hepatitis $B$. The Hepatitis Interventional Therapy Group. N Engl J Med 1990 Aug 2;323(5):295-301. [PubMed]

10. Lok AS, Wu PC, Lai CL, Lau JY, Leung EK, Wong LS, et al. A controlled trial of interferon with or without prednisone priming for chronic hepatitis B. Gastroenterology 1992 Jun;102(6):2091-7. [PubMed]

11. Buster EH, Hansen BE, Lau GK, Piratvisuth T, Zeuzem S, Steyerberg EW, Janssen HL. Factors that predict response of patients with hepatitis B e antigenpositive chronic hepatitis B to peginterferon-alfa. Gastroenterology. 2009 Dec; 137(6):2002-9. Epub 2009 Sep 6. DOI: $\quad 10.1053 / \mathrm{j}$.gastro.2009.08.061 CrossRef] [PubMed]

12. Brunetto MR, Oliveri F, Rocca G, Criscuolo D, Chiaberge E, Capalbo M, et al. Natural course and response to interferon of chronic hepatitis B accompanied by antibody to hepatitis B e antigen. Hepatology. 1989 Aug;10(2):198202. [PubMed]

13. Oliveri F, Santantonio T, Bellati G, Colombatto P, Mels GC, Carriero L, et al. Long term response to therapy of chronic anti-HBe-positive hepatitis B is poor independent of type and schedule of interferon. Am J Gastroenterol. 1999 May;94(5):1366-72. DOI:10.1111/j.1572- 0241.1999.01088.x CrossRef] [PubMed]

14. Manesis EK, Hadziyannis SJ. Interferon a treatment and retreatment of hepatitis $\mathrm{B}$ e antigen-negative chronic hepatitis B. Gastroenterology 2001 Jul;121(1):101-9. DOI: 10.1053/ gast.2001.25524 CrossRef] [PubMed]

15. Bonino F, Marcellin P, Lau GK, Hadziyannis S, Jin R, Piratvisuth T, et al. Predicting response to peginterferon $\mathrm{a}-2 \mathrm{a}$, lamivudine and the two combined for $\mathrm{HBeAg}$ - negative chronic hepatitis B. Gut 2007 May;56(5),699-705. DOI: 10.1136/ gut.2005.089722 CrossRef] [PubMed]

16. Krastev Z, Tchernev K, Petrova D, Nikolovska D, Takov D, Marinova I, et al. Bulgarian Society of Gastroenterology. An open label, multicenter, national nonrandomized study to evaluate efficacy and safety of Peginterferon alfa-2a (40 KD) in patients with $\mathrm{HBeAg-negative} \mathrm{chronic}$ hepatitis B: preliminary results. Bulgarian Hepatogastroenterol. 2006; 2: 90-91. (in Bulgarian)

17. Tcherveniakova T, Strashimirov D, Antonov K, Lilyanova V, Tiholova M, Krastev Z. HBV genotype in Bulgarian patients with acute viral hepatitis $B$. Bulgarian Hepatogastroenterology 2008, 2, 13-16. (in Bulgarian)

18. Lampertico P, Vigano M, Di Costanzo G, Sagnelli E, Fasano M, Di Marko V, Boninsegna S, Farci P, Fargion S, Giuberti T, Iannacone C, Massetto B, Fedeli P, Colombo M, Peg.B.e. Liver study Group. Extended (2 years) treatment with peginterferon alfa-2a (40KD) improves sustained response rates in genotype D patients with $\mathrm{HBeAg-negative}$ chronic hepatitis B. J Hepatol 2010; 52 (Suppl. 1): S45.

\footnotetext{
Address for correspondence:

Dr. Deian Jelev

Clinic of Gastroenterology, St. Ivan Rilsky University Hospital,

15, Acad. Ivan Geshov Blvd., Sofia 1431, Bulgaria

phone: + 3592952 6319; fax: +35928510816

E-mail:dejelev@yahoo.com
} 